\section{References}

1 Office of Population Censuses and Surveys. Registrar General's statistical reviews of England and Wales 1911 et seq. Part 1 . Tables, medical. London: HMSO, 1911 et seq.

2 Barker DJP, Osmond C. Infant mortality, childhood nutrition and ischaemic heart disease in England and Wales. Lancet 1986;i:1077-81.

3 Baird D. Environment and reproduction. Br 7 Obstet Gynaecol 1980;87:1057-67.

4 Baird D. Social factors in obstetrics. Lancet 1949; i: 1079-83.

5 Local Government Board. Forty-fourh annual report 1914-15. Supplement Matemal mortality in connection with childbearing. London: HMSO, 1916.

6 Campbell JM. Maternal mortality. London: HMSO, 1924. (Ministry of Health Reports on Public Health and Medical Subjects, No 25.)

7 Gardner MJ, Winter PD, Barker DJP. Atlas of mortality from selected diseases in England and Wales 1968-78. Chichester: John Wiley, 1984

8 Campbell JM, Cameron D, Jones DM. High matemal mortality in certain areas. London: HMSO, 1932. (Ministry of Health Reports on Public Health and Medical Subjects, No 68.)

9 Hamilton M, Pickering GW, Roberts JAF. The aetiology of essential hypertension. 4. The role of inheritance. Clin Sci 1954;13:273-304.

10 Stamler R, Stamler J, Riedlinger WF, Algera G, Roberts RH. Family (parental) history and prevalence of hypertension. Results of a nationwide screening programme. JAMA 1979;241: 43-6.

11 Evans JG. The epidemiology of stroke. Age Ageing 1979;8 (suppl):50-6.

12 Hofman A. Blood pressure in childhood: an epidemiological approach to the aetiology of hypertension. Journal of Hypertension 1984;2:323-8.

13 de Swiet $M$, Fayers $P$, Shinebourne EA. Blood pressure survey in a population of newborn infants. BrMed f 1976;ii:9-11.

14 Beaglehole R, Salmond CE, Eyles EF. A longitudinal study of blood pressure in Polynesian children. Am $\mathcal{F}$ Epidemiol 1977;105:87-9.

15 Clarke WR, Schrott H, Leaverton PE, Connor WE, Laver RM. Tracking of blood lipids and blood pressure in school age children: the Muscatine study. Circulation 1978;58:626-34.
16 Voors W, Webber LS, Berenson GS. Time course studies of blood pressure in children: the Bogalusa heart study. Am $\mathcal{f}$ Epidemiol 1979;109:320-34.

17 Lee YH, Rosner B, Gould JB, Lowe EW, Kass EH. Familial aggregation of blood pressure of newborn infants and their mothers. Pediatrics 1976;58:722-9.

18 Zinner SH, Rosner B, Oh W, Kass EH. Significance of blood pressure in infancy: familial aggregation and predictive effect on later blood pressure. Hyperiension 1985;7:411-6.

19 Ibsen KK, Gronback M. Familial aggregation of blood pressure in newly born infants and thei mothers. Acta Paediatr Scand 1980;69:109-11

20 Wadsworth MEJ, Cripps HA, Midwinter RE, Colley JRT. Blood pressure in a national birth cohort at the age of 36 related to social and familial factors, smoking, and body mass. Br Med $\mathcal{J}$ 1985;291:1534-8.

21 Simpson A, Mortimer JG, Silva PA, Spears G, Williams S. In: Onesti G, Kim KE, eds. Hypertension in the young and old. New York: Grune and Stratton, 1981:153-63.

22 Cater J, Gill M. The follow-up study: medical aspects. In: Illsey R, Mitchell RG, eds. Low birthweight, a medical, psychological and social study. Chichester: John Wiley, 1984:191-205.

23 Ounsted MK, Cockburn JM, Moar VA, Redman CWG. Factors associated with the blood pressures of children born to women who were hypertensive during pregnancy. Arch Dis Child 1985;60:631-5.

24 Paffenberger RS, Wing AL. Characteristics in youth predisposing to fatal stroke in later years. Lancet 1967; i:753-4.

25 Heyden S, Hames CG, Bartel A, Cassel JC, Tyroler HA, Goree JA. Weight and weight history in relation to cerebrovascular and ischaemic heart disease. Arch Intern Med 1971;128:956-60.

26 Evans JG, Prudham D, Wandless I. Risk factors for stroke in the elderly. In: Sangiorgi GB Exton-Smith AN, eds. The ageing brain, neurological and mental disturbances. New York: Plenum Publishing Corp, 1980:113-26.

27 Acheson RM, Williams DRR. Epidemiology of cerebrovascular disease: some unanswered questions. In: Rose FC, ed. Clinical neuroepidemiology. London: Pitman Medical, 1980:88-104.

\title{
Type A behaviour and ischaemic heart disease in middle aged British men
}

\author{
D W JOHNSTON, D G COOK, A G SHAPER
}

\begin{abstract}
The Bortner questionnaire, which measures aspects of type A (coronary prone) behaviour, was completed by 5936 men aged 40 59 selected at random from one general practice in each of 19 British towns. The presence of ischaemic heart disease was determined at initial examination and the men were followed up for an average of 6.2 years for morbidity and mortality from myocardial infarction and for sudden cardiac death.

Non-manual workers had significantly higher scores (more type A) than manual workers and the score decreased (less type A) with increasing age. After adjustment for social class and age men with higher scores had higher prevalences of ischaemic heart disease less marked for electrocardiographic evidence and more marked for response to a chest pain questionnaire (angina or possible myocardial infarction). A man's recall of a doctor's diagnosis of ischaemic heart disease, however, did not relate to his Bortner score. There was no significant relation between the Bortner score and the attack rate or incidence of major ischaemic heart disease events.

In this study type $\mathbf{A}$ behaviour, as measured by the Bortner questionnaire, did not predict major ischaemic heart disease events in British middle aged men.
\end{abstract}

\footnotetext{
Department of Psychology, St George's Hospital Medical School, London SW17 ORE

D W JOHNSTON, MA, PHD, research psychologist

Department of Clinical Epidemiology and General Practice, Royal Free Hospital School of Medicine, London NW3 2QG

D G COOK, MSC, lecturer in medical statistics

A G SHAPER, FRCP, FRCPATH, professor of clinical epidemiology

Correspondence to: Dr Johnston.
}

\section{Introduction}

Type A or coronary prone behaviour is characterised by intense competitiveness, a sense of being under time pressure, and easily provoked hostility. Type A behaviour has been shown to relate to the prevalence and incidence of ischaemic heart disease independently of the traditional risk factors of hypertension, hypercholesterolaemia, and cigarette smoking in several countries, but it has not been examined extensively in the United Kingdom. ${ }^{1-3}$

We describe the relation between type $A$ behaviour and the prevalence and attack rate of ischaemic heart disease in roughly 6000 middle aged British men selected at random from one general practice in each of 19 British towns as part of the British regional heart study. Type A behaviour was assessed by using the Bortner questionnaire, a 14 item questionnaire which is used extensively in Great Britain and western Europe. ${ }^{4}$ We find that it has adequate reliability and that it relates well to the Jenkins activity survey, the questionnaire more widely used in North America. ${ }^{5}$

\section{Subjects and methods}

The British regional heart study is a prospective study of men aged 40-59 randomly selected from the age-sex registers of one group general practice in each of 24 towns in England, Wales, and Scotland. The 24 towns were primarily selected from those with populations of 50000-100000 (1971 census). They were chosen to represent the full range of cardiovascular disease mortality and included towns in all the main regions. Each general practice was selected to have a social class distribution which was more or less representative of the men of that town. From each age-sex register some 420 men aged 40-59 were randomly selected and in a letter signed by their general practitioner invited to take part. On average $78 \%$ of those invited attended for examination and 7735 men were screened. The Bortner questionnaire was given to the 6177 men in the last 19 towns to complete while they waited to be examined. This paper is concerned with the 5936 men who satisfactorily completed the Bortner questionnaire. 
Pre-existing ischaemic heart disease-The presence of ischaemic heart disease at the initial examination was assessed $(a)$ by means of a questionnaire asking about chest pain (definite or possible angina or possible myocardial infarction), (b) by taking a resting electrocardiogram, and $(c)$ by asking the men if a doctor had ever told them that they had ischaemic heart disease (angina, heart attack, myocardial infarction). ${ }^{67}$ Electrocardiographic evidence of ischaemic heart disease included definite or possible myocardial infarction and definite myocardial ischaemia. In this paper possible ischaemia is not included as evidence of ischaemic heart disease.

TABLE I-Bortner scores of men stratified by social class (four men not classed)

\begin{tabular}{lrrr}
\hline & & \multicolumn{2}{c}{ Bortner score } \\
\cline { 3 - 4 } Social class & No of men & Mean & SD \\
\hline I (Professional) & 483 & $100 \cdot 09$ & $18 \cdot 21$ \\
II (Managerial) & 1260 & $101 \cdot 90$ & $18 \cdot 84$ \\
III (Clerical) & 534 & $93 \cdot 01$ & $19 \cdot 21$ \\
III (Skilled manual) & 2615 & $91 \cdot 60$ & $19 \cdot 40$ \\
IV (Semiskilled manual & 616 & $88 \cdot 54$ & $18 \cdot 26$ \\
V (Unskilled manual) & 258 & $84 \cdot 27$ & $20 \cdot 12$ \\
Armed services & 166 & $95 \cdot 15$ & 18.95 \\
\hline
\end{tabular}

TABLE II-Bortner scores stratified by smoking category (six men not classified for smoking)

\begin{tabular}{|c|c|c|c|c|}
\hline \multirow[b]{2}{*}{ Smoking category } & \multirow{2}{*}{$\begin{array}{c}\text { No of } \\
\text { men }\end{array}$} & \multicolumn{3}{|c|}{ Bortner score } \\
\hline & & Mean & SD & Adjusted mean * \\
\hline $\begin{array}{l}\text { Never smoked } \\
\text { Non-smoker (ex-cigarette smoker) } \\
\text { Pipe or cigar smoker only } \\
\text { Pipe or cigar smoker (ex-cigarette smoker) } \\
\text { Cigarette smoker }\end{array}$ & $\begin{array}{r}1234 \\
1611 \\
128 \\
472 \\
2485\end{array}$ & $\begin{array}{l}96 \cdot 54 \\
96 \cdot 41 \\
94 \cdot 52 \\
94 \cdot 33 \\
91 \cdot 22\end{array}$ & $\begin{array}{l}19 \cdot 44 \\
19 \cdot 45 \\
19 \cdot 62 \\
19 \cdot 77 \\
19 \cdot 75\end{array}$ & $\begin{array}{l}94 \cdot 98 \\
96 \cdot 35 \\
92 \cdot 51 \\
93 \cdot 98 \\
92 \cdot 24\end{array}$ \\
\hline
\end{tabular}

^Adjusted for age and social class.

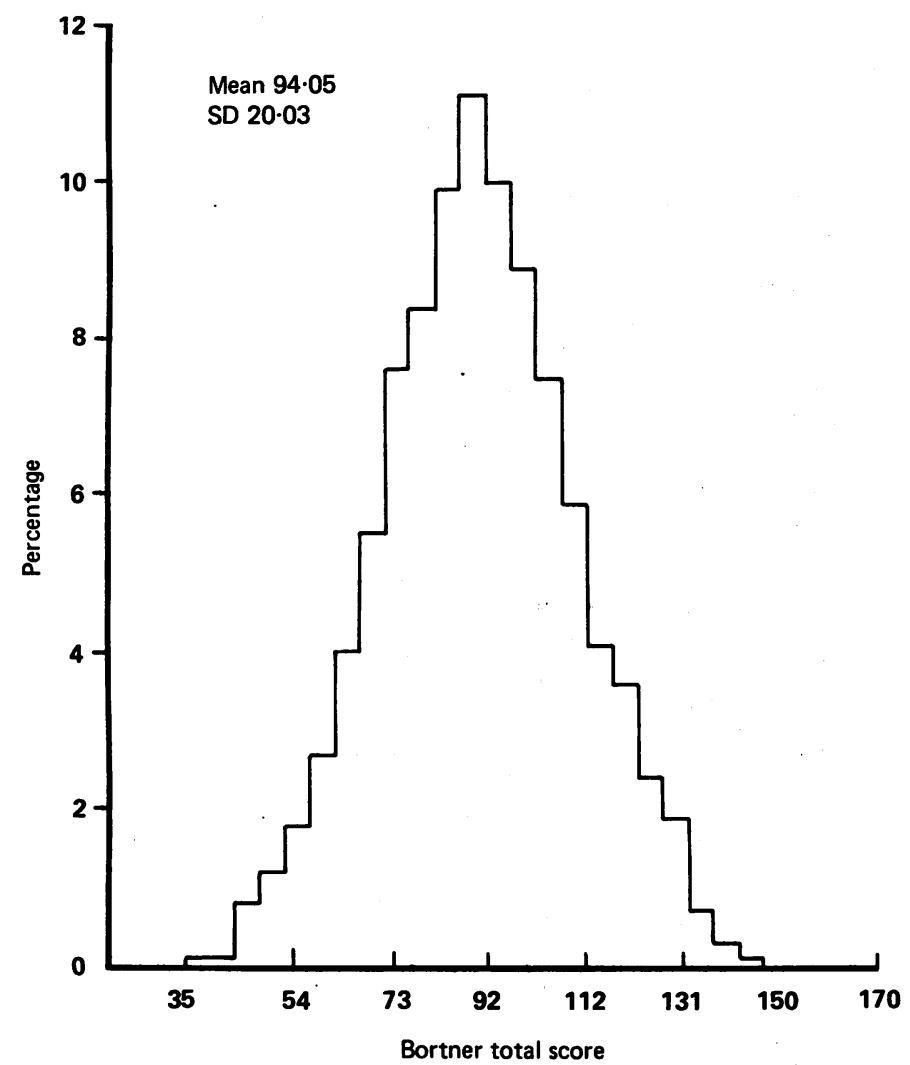

Distribution of Bortner scores in sample of 5936 men.
Follow up and major new cardiovascular events-All the men who participated in the initial examination were being followed up for both cardiovascular morbidity and all causes of mortality. ${ }^{8}$ In this report a fatal case is any subject for whom the death certificate recorded ischaemic heart disease (International Classification of Diseases (9th revision) codes 410-414) and a non-fatal case any subject with a reported myocardial infarction supported by at least two of the following: infarction preceded by severe prolonged chest pain; electrocardiographic evidence of myocardial infarction; and cardiac enzyme changes. ${ }^{9}$ Up to July 1985 all men had been followed up for between $5 \cdot 0$ and $7 \cdot 5$ years (average 6.2 years).

Bortner questionnaire-Each of the 14 questions in the Bortner questionnaire was scored 1-12, type A behaviour scoring 12 , and the total summed to produce an overall score between 14 and 168 . Other workers have scored the questions 1-24 and hence report higher values. For the 343 questionnaires with one item missing and the 45 with two items missing the total was calculated on the scored items and scaled up proportionately. The 241 questionnaires not satisfactorily completed were excluded from the analysis.

Blood pressure and blood cholesterol values-The London School of Hygiene sphygmomanometer was used to measure the blood pressure twice in succession with the subject seated. Diastolic pressure was recorded at the point of disappearance of sounds (phase V). The mean of these two readings adjusted for observer variation was used for the analysis. Serum total cholesterol concentration was measured by a modified Liebermann-Burchard method. ${ }^{10}$

Social class was determined from each man's longest held occupation by using the six classes of the Registrar General's 1970 classification. ${ }^{11}$ Men who had spent most of their working life in one of the armed services formed a separate group.

Smoking - The men were grouped as follows according to their current smoking state: non-smokers, ex-cigarette smokers, pipe or cigar smokers, ex-cigarette smokers who had changed to pipe or cigar, and current cigarette smokers.

Statistical methods_-In tables I and II the distribution of Bortner scores stratified by social class and smoking category is presented as means and standard deviations (SD). In table II the adjusted means for smoking categories are based on analysis of covariance. The prevalence and attack rates of ischaemic heart disease are presented by quintiles of the Bortner score. Rates adjusted for age and social class were obtained by fitting logistic regressions in which the ischaemic heart disease measure treated as a 0,1 variable was regressed on the Bortner score (fitted as four dummy variables), age (fitted as a continuous variable), and social class (fitted as six dummy variables). Statistical significance of any trend in prevalence or attack rates was assessed by fitting the Bortner score as a continuous variable rather than as four dummy variables in the appropriate logistic regression.

\section{Results}

The distribution of Bortner scores for the total sample (figure) showed a normal distribution with a mean of 94 . There appeared to be little relation between the Bortner score and the major risk factors for ischaemic heart disease; the correlation coefficient was -0.07 with systolic blood pressure, 0.02 with diastolic blood pressure, and 0.03 with serum total cholesterol concentration. These small correlations were statistically significant because of the large numbers studied. The correlation of -0.09 with age was of slightly greater relevance as the prevalence and attack rate of ischaemic heart disease are so much higher in older men.

Table I shows the relation between the Bortner score and social class. There was a strong association, non-manual workers having significantly higher scores than manual workers. The relation with smoking (table II) showed somewhat higher scores in men who had never smoked and in men who had given up cigarette smoking completely. Pipe and cigar smokers had slightly lower scores, and those currently smoking cigarettes at screening had the lowest scores of all. The relation between smoking and the Bortner score was confounded by the effects of social class and age, as current cigarette smoking is more common among manual workers and ex-smokers tend to be older. Bortner scores adjusted for social class and age in table II show a reduced mean difference between cigarette smokers and men who had never smoked.

Prevalence of ischaemic heart disease-Table III shows the percentage prevalence of ischaemic heart disease at entry into the study stratified by quintiles of the Bortner score. With the rates unadjusted the prevalence of both electrocardiographic and questionnaire evidence of ischaemic heart disease was positively related to the Bortner score, though the relation for electrocardiographic prevalence was weak and not significant at the $5 \%$ level. Because of the possible confounding effects of other factors we carried out preliminary analyses in which the prevalence rates were adjusted for blood pressure, age, serum total cholesterol value, smoking, and social class. As only social class and age had any effect, table III presents the rates adjusted for these two factors. After adjustment the trends were significant for both 
the electrocardiographic and the questionnaire evidence. A man's recall of a diagnosis of ischaemic heart disease made by a doctor did not relate to the Bortner score before or after adjustment.

New major ischaemic heart disease events-Table IV shows the attack rates of new major ischaemic heart disease events, non-fatal and fatal, stratified by quintiles of the Bortner score. Overall the attack rate was higher among men with lower Bortner scores-that is, type B men. This negative trend, however, was not significant at the $5 \%$ level. Adjustment for age and social class had the expected outcome of reducing the trend. The significant negative trend in the fatal event rate with increasing Bortner score was also
The structured interview showed type $\mathrm{A}$ behaviour to be a risk factor for ischaemic heart disease in two out of three studies, ${ }^{16-18}$ the Jenkins activity scale in two out of five,,$^{17} 1920$ the Bortner score in two out of four,,$^{12}$ and the Framingham questionnaire on the one occasion on which it was used. ${ }^{21}$ There was no striking difference among the methods used in the positive and negative studies. It does not appear that any one method of measuring type A behaviour is more successful, though many argue that the structured interview is the most satisfactory. In studies in which type A behaviour was

TABLE III-Percentage prevalence of ischaemic heart disease at screening stratified by quintiles of Bortner score. (SE in parentheses)

\begin{tabular}{|c|c|c|c|c|c|c|c|}
\hline \multirow{2}{*}{$\begin{array}{l}\text { Bortner } \\
\text { range }\end{array}$} & \multirow{2}{*}{$\begin{array}{l}\text { No of } \\
\text { men }\end{array}$} & \multicolumn{2}{|c|}{ Electrocardiogram } & \multicolumn{2}{|c|}{ Chest pain (questionnaire) } & \multicolumn{2}{|c|}{ Recall } \\
\hline & & Crude & Adjusted ${ }^{\star}$ & Crude & Adjusted ${ }^{\star}$ & Crude & Adjusted ${ }^{\star}$ \\
\hline $\begin{array}{c}26-77 \\
78-89 \\
90-98 \\
99-110 \\
111-163\end{array}$ & $\begin{array}{l}1158 \\
1264 \\
1136 \\
1206 \\
1172\end{array}$ & $\begin{array}{l}7 \cdot 0(0.7) \\
7 \cdot 7(0.7) \\
7.6(0.8) \\
7.9(0.8) \\
8.7(0.8)\end{array}$ & $\begin{array}{l}6 \cdot 4 \\
7 \cdot 5 \\
7 \cdot 6 \\
8 \cdot 0 \\
9 \cdot 3\end{array}$ & $\begin{array}{l}14 \cdot 4(1 \cdot 0) \\
11 \cdot 8(0 \cdot 9) \\
14 \cdot 7(1 \cdot 1) \\
14 \cdot 9(1 \cdot 0) \\
17 \cdot 3(1 \cdot 1)\end{array}$ & $\begin{array}{l}12 \cdot 8 \\
11 \cdot 2 \\
14 \cdot 5 \\
15 \cdot 3 \\
19 \cdot 0\end{array}$ & $\begin{array}{l}6.6(0.7) \\
4.0(0.6) \\
5.7(0.7) \\
6 \cdot 1(0.7) \\
5.8(0.7)\end{array}$ & $\begin{array}{l}5 \cdot 8 \\
3 \cdot 8 \\
5 \cdot 6 \\
6 \cdot 3 \\
6 \cdot 6\end{array}$ \\
\hline p Value & & 0.22 & 0.03 & 0.04 & 0.00001 & 0.98 & $0 \cdot 12$ \\
\hline
\end{tabular}

^Adjusted for age and social class.

TABLE IV-Percentage attack rates of major new ischaemic heart disease stratified by quintiles of Bortner score. (SE in parentheses)

\begin{tabular}{|c|c|c|c|c|c|}
\hline \multirow{2}{*}{$\begin{array}{l}\text { Bortner } \\
\text { range }\end{array}$} & \multirow{2}{*}{$\begin{array}{l}\text { No of } \\
\text { men }\end{array}$} & \multicolumn{3}{|c|}{ Crude attack rate } & \multirow{2}{*}{$\begin{array}{l}\text { Adjusted attack } \\
\text { rate }\end{array}$} \\
\hline & & Non-fatal & Fatal & Both & \\
\hline $\begin{array}{c}26-77 \\
78-89 \\
90-98 \\
99-110 \\
111-163\end{array}$ & $\begin{array}{l}1158 \\
1264 \\
1136 \\
1206 \\
1172\end{array}$ & $\begin{array}{l}2.9 \\
1.8 \\
1.6 \\
2 \cdot 4 \\
2 \cdot 5\end{array}$ & $\begin{array}{l}2.3 \\
2.8 \\
1.7 \\
1.9 \\
1.3\end{array}$ & $\begin{array}{l}5.3(0.7) \\
4.7(0.6) \\
3.3(0.5) \\
4.3(0.6) \\
3.8(0.6)\end{array}$ & $\begin{array}{l}4 \cdot 7 \\
4 \cdot 5 \\
3 \cdot 3 \\
4 \cdot 5 \\
4 \cdot 2\end{array}$ \\
\hline $\mathrm{p}$ Value & & 0.86 & 0.01 & $0 \cdot 10$ & 0.64 \\
\hline
\end{tabular}

^Adjusted for age and social class.

reduced to non-significance $(p=0 \cdot 23)$ when social class and age were adjusted for. The results were unchanged when the data were reanalysed excluding all respondents with evidence of pre-existing ischaemic heart disease at screening.

\section{Discussion}

In this study of middle aged British men the Bortner score for type A behaviour was significantly higher in men who had electrocardiographic or questionnaire evidence of ischaemic heart disease at screening. This did not hold for men recalling a doctor's diagnosis of angina or myocardial infarction. Type A behaviour did not relate to the occurrence of major new ischaemic heart disease events during an average of $6 \cdot 2$ years of follow up.

Our findings with respect to type $A$ behaviour and the prevalence of ischaemic heart disease are in general agreement with published findings. In most such studies type A behaviour related to the prevalence of ischaemic heart disease $\mathrm{e}^{12-14}$ and appeared to do so most clearly from measures derived from symptoms such as chest pain. One interpretation is that in men with pre-existing ischaemic heart disease and a tendency to symptomatic ischaemia pain may be precipitated by type A behaviour. ${ }^{15}$

The lack of relation between the Bortner scores and subsequent myocardial infarction or sudden death in this study should be seen against the background of other prospective studies. We have identified eight studies including the present report. Four methods of measuring type A behaviour have been used in these studies: the structured interview (the original measure), the Jenkins activity scale, the Bortner score, and the Framingham questionnaire. found to be a significant risk factor it was of comparable power to other risk factors such as systolic blood pressure or total serum cholesterol concentration, which suggests that type A behaviour is not simply a weak risk factor that achieves marginal significance in some studies. It may be relevant that it has recently been claimed that hostility, which was not specifically addressed in any of these studies, may be the aspect of type A behaviour that correlates best with coronary artery disease. ${ }^{22} 23$ It is quite likely that the relation between type $\mathrm{A}$ behaviour and hostility varies among different cultures and subcultures and hence measures of type A behaviour may not always include this relevant behaviour.

We have not found type A behaviour, as measured by the Bortner questionnaire, to relate to new major ischaemic heart disease events in a British middle aged male population. Though it is possible that some aspects of type $A$ behaviour predispose subjects in some populations to ischaemic heart disease, it is not at present clear which aspects these are or in whom they are most important.

The British regional heart study is a British Heart Foundation research group and also receives support from the Medical Research Council and Department of Health and Social Security. The electrocardiographic studies (Dr P W MacFarlane) were supported by the Scottish Home and Health Department and the Greater Glasgow Health Board. Serum total cholesterol measurements were carried out in the Wolfson Research Laboratories (Professor T P Whitehead) with support from the Department of Health and Social Security.

\section{References}

1 Review Panel on Coronary-Prone Behavior and Coronary Heart Disease. Coronary-prone behavior and coronary heart disease: a critical review. Circulation 1981;63:1199-215.

2 Heller RF. Type A behaviour and coronary heart disease. Br Med f 1979;ii:368.

3 Gallacher JEJ, Yarnell JWG, Elwood PC, Phillips KM. Type A behaviour and heart disease in men in the Caerphilly study. Br Med f 1984;289:732-3.

4 Bortner RW. A short rating scale as a potential measure of pattern A behavior. $\mathcal{J}$ Chronic Dis 1969;22:87-91.

5 Johnston DW, Shaper AG. Type A behavior in British men: reliability and intercorrelation of two measures. $\mathcal{F}$ Chronic Dis 1983;36:203-7.

6 Shaper AG, Cook DG, Walker M, MacFarlane PW. Prevalence of ischaemic heart disease in middle-aged British men. Br Heart $\mathcal{f}$ 1984;51:595-605.

7 Shaper AG, Cook DG, Walker M, MacFarlane PW. Recall of diagnosis by men with ischaemic heart disease. Br Heart f 1984;51:606-11.

8 Walker $M$, Shaper AG. Follow-up of subjects in prospective studies based in general practice. IR Coll Gen Pract 1984;34:365-70.

9 Shaper AG, Pocock SJ, Walker M, Phillips AN, Whitehead TP, MacFarlane PW. Risk factors for ischaemic heart disease: the prospective phase of the British regional heart study. $\mathcal{I}$ Epidemiol ischaemic heart disease: the prospective

10 Thelle DS, Shaper AG, Whitehead TP, Bullock DG, Ashby D, Patel ILA. Blood lipids in middleaged British men. Br Hear $\mathcal{f}$ 1983;49:205-13.

11 Office of Population Censuses and Surveys. Classification of occupations 1970. London: HMSO, 1970. 
12 Shekelle RB, Schoenberger JA, Stamler J. Correlates of the JAS type A behavior pattern score. J Chronic Dis 1976;29:381-94.

13 Haynes SG, Feinleib M, Levine S, Scotch N, Kannel WB. The relationship of psychosocial factors to coronary heart disease in the Framingham study II. Prevalence of coronary heart disease. Am J Epidemiol 1978; 107:384-402.

14 French-Belgian Collaborative Group. Ischaemic heart disease and psychological patterns. Adv Cardiol 1982;29:25-31.

15 Freeman $Z$. Is type A behaviour a cause of coronary heart disease? Med f Aust 1986;145:262-70. 16 Rosenman RH, Brand RJ, Jenkins CD, Friedman M, Straus R, Wurm M. Coronary heart disease in the Western Collaborative Group study: final follow-up experience of $8^{1 / 2}$ years. $\mathscr{f A M A}$ in the Western

17 Kittel F. Type A and other psychosocial factors in relation to CHD. In: Schmidt TD, Dembroski TD, Blumchen C, eds. Biological and psychological factors in cardiovascular disease. Berlin Springer Verlag, 1986:63-84.
18 Shekelle RB, Hulley SB, Neaton JD, et al. The MRFIT behavior pattern study. II: type A behavior and the incidence of coronary heart disease. Am $\mathcal{J}$ Epidemiol 1985;122:559-70.

19. Jenkins CD, Rosenman RH, Zyzanski SJ. Prediction of clinical coronary heart disease by a test of the coronary-prone behavior pattern. N Engl f Med 1974;290:1271-5.

20 Cohen JB, Reed D. The type A pattern and coronary heart disease among Japanese men in Hawaii. I Behav Med 1985;4:343-52.

21 Haynes SG, Feinleib M, Kannel WB. The relationship of psychosocial factors to coronary heart disease in the Framingham study. III: eight-year incidence of coronary heart disease. Am $\mathcal{J}$ Epidemiol 1980;111:37-58.

22 Shekelle RB, Gale M, Ostfeld A, Paul O. Hostility, risk of coronary heart disease and mortality. Psychosom Med 1983;45:109-14.

23 Manuck SB, Kaplan TR, Matthews KA. Behavioral antecedents of coronary heart disease and atherosclerosis. Anteriosclerosis 1986;6:2-14.

(Accepted 22 May 1987)

\title{
Lethal malformations and perinatal mortality: a 10 year review with comparison of ethnic differences
}

\author{
I D YOUNG，M CLARKE
}

\begin{abstract}
During 1976 to 1985 perinatal mortality in Leicestershire decreased from 21 to 9.5 per 1000 births. Throughout this period the incidence of lethal malformations, excluding neural tube defects, remained relatively constant at around 1.8 per 1000 births. Analysis of the malformations present in 201 lethally malformed babies showed that $147(73 \%)$ had a disorder carrying a recurrence risk of $1 \%$ or greater. Only $7 \%$ of these malformations might have been predicted from the family history or advanced maternal age. The incidence of lethal malformations was significantly increased in the Asian population, largely because of an excess of autosomal recessive disorders.

The contribution of lethal malformations to perinatal mortality has almost doubled over the past 10 years and is likely to increase despite prenatal diagnosis and improvements in obstetric and paediatric services.
\end{abstract}

\section{Introduction}

Malformations account for a substantial proportion of perinatal mortality in the United Kingdom, with figures of $26 \%$ and $34 \%$ having been observed in recent studies. ${ }^{12}$ Given the decline in other causes of perinatal death and the recent unexplained reduction in the incidence of neural tube defects, ${ }^{3}$ attention will probably focus increasingly on babies with malformations other than neural tube defects, whose relative contribution to perinatal mortality is likely to increase despite existing or planned improvements in obstetric and paediatric services.

In 1976 a comprehensive survey of perinatal mortality was launched in Leicestershire (population 833000), a county which readily lends itself to epidemiological study as obstetric and paediatric services are based in two centrally located teaching hospitals, thus facilitating the collection of relevant information. Using data from the first 10 years of this survey we reviewed the

Departments of Child Health and Community Health, University of Leicester, Leicester LE2 7LX

I D YOUNG, MD, MRCP, senior lecturer in child health (clinical genetics) M CLARKE, DPH, FFCM, professor of epidemiology

Correspondence to: Dr I D Young, Department of Child Health, Clinical Sciences Building, Leicester Royal Infirmary, PO Box 65, Leicester LE2 7LX. records of babies dying as a result of malformations, excluding neural tube defects. The objectives of this study were $(a)$ to ascertain whether there had been any change in the overall incidence of lethal malformations over 10 years; (b) to establish the aetiological range and its genetic component; $(c)$ to estimate the possible impact of genetic counselling and prenatal diagnostic surveillance; and $(d)$ to identify possible ethnic differences.

\section{Methods}

Babies were ascertained through the records of the Leicestershire perinatal mortality survey, full details of which have been recorded elsewhere. ${ }^{45}$ Strenuous efforts were made to review the records of all babies along with necropsy reports, radiographs, and clinical photographs. Babies were included in the study only if death was due primarily to a malformation, so that babies who had a relatively minor abnormality, which was coincidental rather than causally related to their death, were not included. When appropriate recourse was made to expert opinion and the London dysmorphology database to help establish the diagnosis. ${ }^{6}$

The results presented below refer to lethal malformations other than isolated non-syndromic neural tube defects.

\section{Results}

\section{INCIDENCE OF LETHAL MALFORMATIONS}

Table I gives the birth statistics for Leicestershire for 1976-85. During this period 208 babies died in the perinatal period primarily as the direct result of a malformation or malformations: an overall incidence of $1.80 \mathrm{per}$

TABLE I-Birth statistics for Leicestershire 1976-85

\begin{tabular}{|c|c|c|c|c|c|c|c|}
\hline & \multicolumn{3}{|c|}{ Deaths due to malformations } & \multirow{2}{*}{$\begin{array}{l}\text { Total perinatal } \\
\text { deaths }\end{array}$} & \multicolumn{3}{|c|}{ Total births } \\
\hline & White & Asian & Total & & White & Asian & Total \\
\hline 1976 & 15 & 3 & 18 & 230 & 9752 & 1123 & 10875 \\
\hline 1977 & 20 & 4 & 24 & 190 & 9549 & 1286 & 10835 \\
\hline 1978 & 19 & 4 & 23 & 196 & 9784 & 1276 & 11060 \\
\hline 1979 & 19 & 4 & 23 & 172 & 10388 & 1366 & 11754 \\
\hline 1980 & 18 & 4 & 22 & 151 & 10822 & 1524 & 12346 \\
\hline 1981 & 16 & 5 & 21 & 118 & 10273 & 1518 & 11791 \\
\hline 1982 & 12 & 4 & 16 & 130 & 10061 & 1496 & 11557 \\
\hline 1983 & 16 & 7 & 23 & 122 & 9979 & 1565 & 11544 \\
\hline 1984 & 11 & 4 & 15 & 101 & 10161 & 1625 & 11786 \\
\hline 1985 & 18 & 5 & 23 & 114 & 10375 & 1582 & 11957 \\
\hline Total & 164 & 44 & 208 & 1524 & 101144 & 14361 & 115505 \\
\hline
\end{tabular}

